\title{
Alat Permainan Edukatif dalam Menanamkan Nilai Agama dan Moral Anak Usia Dini
}

\section{Ahmad Aly Syukron Aziz Al Mubarok}

Institut Agama Islam Uluwiyah, Mojokerto, Indonesia syukron99@gmail.com

Abstract: Educational Play Tools in Instilling Religious and Moral Values in Early Childhood. This research was conducted to support the educational game tools improvement in instilling religious and moral values. This research method uses Classroom Action Research (CAR) which aims to instill religious and moral values at the early childhood level. This research was conducted at an early childhood education institution, namely $R A$. Al Musthofa Bangsal. The results of the research through observation from cycles I and II experienced classical learning completeness, namely in the first cycle of meeting 1 the average score of children was 52 completeness $25 \%$. Meeting 2 the average score of the child was 61 completeness $42 \%$. Meeting 3 the mean score of children is 63 completeness 50\%. cycle II meeting 1 the average value of the child 67 completeness 58\%. Meeting 2 the mean score of children 75 completeness $75 \%$. While meeting 3 the average score of children is 88 completeness $91 \%$ means very well developed.

Keywords: Educational play tools, religious values, moral values.

Abstrak: Penelitian ini dilakukan bertujuan untuk memberikan dukungan terhadap peningkatan Alat permainan edukatif dalam menanamkan nilai-nilai agama dan moral. Metode Penelitian ini menggunakan Classroom Action Research (CAR) yang bertujuan untuk menanamkan nilai-nilai agama dan moral pada tingkatan anak usia dini. Penelitian ini dilakukan di lembaga pendidikan anak usia dini 
yaitu RA. Al Musthofa Bangsal. Hasil penelitian melalui Observasi dari siklus I dan II mengalami ketuntasan belajar kelasikal yaitu pada siklus I pertemuan 1 di peroleh nilai rata-rata anak 52 ketuntasan 25\%. Pertemuan 2 nilai rata-rata anak 61 ketuntasan 42\%. Pertemuan 3 nilai rata-rata anak 63 ketuntasan 50\%. siklus II pertemuan 1 nilai rata-rata anak 67 ketuntasan 58\%. Pertemuan 2 nilai rata-rata anak 75 ketuntasan 75\%. Sedangkan pertemuan 3 nilai rata-rata anak 88 ketuntasan 91\% artinya Berkembang sangat Baik.

Kata kunci: Alat permainan edukatif, nilai agama, nilai moral.

\section{A. Pendahuluan}

APE PAUD adalah segala sesuatu yang dapat digunakan sebagai sarana atau peralatan bermain anak usia dini, yang mengandung nilai pendidikan dan dapat mengoptimalkan perkembangan anak. Pada dasarnya APE untuk PAUD sengaja dirancang secara khusus untuk kepentingan pendidikan dan dirancang untuk tujuan meningkatkan aspek perkembangan anak PAUD (Sulastri et al., 2017). Seiring dengan bertambahnya tahun teknologi semakin maju dan ramai di perbincangkan di tengah masyarakat mengenai penggunaan HP. HP merupkan teknologi yang canggih yang bisa digunakan komunikasi jarak jauh. Alat komunikasi tersebut tidak hanya kalangan dewasa saja saat ini sudah merambah ke dunia anak. Data di lapangan diperoleh sebanyak 98\% responden anak-anak di Asia Tenggara tersebut menggunakan gadget atau perangkat seluler (mobile device), kebanyakan gadget digunakan sebagai media atau alat bermain, yakni untuk memainkan aplikasi permainan (games) dalam(Saputra \& Ekawati, 2017). Pengembangan dan pemanfaatannya alat permainan yang digunakan anak di TK itu dirancang secara khusus untuk perkembangan anak. Bahwa alat permainan edukatif adalah alat yang dirancang khusus sebagai alat untuk bantu belajar dan dapat mengoptimalkan perkembangan anak, disesuaikan dengan usia dan tingkat perkembangannya(Syamsuardi, 2012).

Usia 1 hari sampai 6 tahun merupakan usia keemasan anak usia dini yang disebut golden age dimana anak berkembang dan tumbuh sangat cepat dalam berbagai aspek. Masa awal anak 
usia dini adalah masa-masa berkembang dan tumbuh secara berkala sepanjang kehidupan manusia(P. A. Indrawan et al., 2017).Menurut Wiyani dalam (Putra Made, Komang Dewi Sukaryasih, 2016) permainan sangat besar pengaruhnya terhadap perkembangan karakter anak, seperti karakter mandiri apabila permainan tersebut didesain dengan baik, dengan menggabungkan aspek rekreatif dan edukatif. Pribadi yang mandiri merupakan kemampuan hidup yang utama bagi setiap individu di awal usianya. Meskipun usia anak masih terlihat sangat muda, anak diharuskan memiliki pribadi yang mandiri. Bila anak sudah memiliki pribadi yang mandiri, anak sudah tidak akan tergantung lagi kepada orang tua atau orang dewasa lainnya disaat anak mulai terjun langsung untuk mengenal lingkungan sekitarnya. APE, lagi dikenal sebagai permainan edukatif dengan memetik keuntungan dari asas dan teknologi permainan untuk mennghasilkan materi pendidikan(Indriasih, 2015).Agama sangat berperan dalam pembentukan perilaku anak, sehingga pembentukan pribadi anak akan membaur sesuai pertumbuhan dan perkembangan anak. Sehingga diperlukan pendidikan dengan persyaratanpersyaratan tertentu dan pengawasan serta pemeliharaan yang terus-menerus(Sapendi, 2015).

Penanaman nilai moral dan agama menurun, maka amat penting bagi AUD, pemuda dan dewasa sebagai generasi penerus bangsa untuk meningktkan, supaya hargadiri bangsa bisa meningkat, kualitas hidup meningkat, kehidupan menjadi lebih baik, aman dan nyaman serta sejahtera. Pendidikan ini membentuk generasi penerus yang berotak Jerman dan berhati Mekah yang mencerminkan keseimbangan antara ilmu pengetahuan dan pengamalan nilai moral/agama(Nawawi, 2010). Tata nilai, etika berarti nilai-nilai agama dan moral yang menjadi kunci seseorang dalam mengatur tingkah lakunya(I. Indrawan, 2016). Kemudian setelah meraka tumbuh dan berkembang menjadi anak-anak, maka yang pertama harus ditanamkan ialah nilai-nilai agama yang berkaitan dengan keimanan, bersamaan dengan itu anak-anak juga di bimbing nilai-nilai moral(Nurmadiah, 2016).Nilai agama dan akhlak (moral) sangat penting bagi kehidupan suatu bangsa. Dalam dunia pendidikan, pembinaan akhlak merupakan salah satu fungsi untuk memperbaiki kehidupan bangsa, selain itu perlu juga adanya pengembangan ilmu. Negara Indonesia 
memercayai adanya dua fungsi tersebut itu terikat dengan baik. Bilamana fungsi akhlak/moral dilalaikan, terjadi pemuliaan pada ilmu pengetahuan secara bermewah-mewahan dan manusia akan menjurus pada sifat menyendiri, yang akhirnya akan menimbulkan pertikaian di antara manusia. Sebaliknya, apabila pendidikan hanya mementingkan akhlak, akan timbul kemacetan kreasi yang menyebabkan(Inawati, 2017). Sebagai sistem nilai, etika berarti nilai-nilai dan norma-norma moral yang menjadi pegangan bagi seseorang atau kelompok dalam mengatur tingkah lakunya(I. Indrawan, 2016). Nilai Agama dan moral pada program PAUD adalah pondasi yang kuat dan sangat penting adanya, dan jika keadaan itu telah terpatri serta tertanam denga baik dalam setiap anak sejak dini, keadaan tersebut melahirkan awal yang baikbagi pendidikan anak bangsa untuk menjalani pendidikan seterusnya. Bangsa Indonesia benar-benar menjunjung tinggi nilai-nilai agama dan moral. Berdasarkan pengamatan di RA Al Musthofa Bangsal, masalah yang teridentifiksi yaitu: 1) Kurangnya metode pembelajaran yang mudah dan menarik bagi anak. 2) Masih terbatasnya alat permainan edukatif untuk bermain. 3) Kurangnya penanaman nilai agama anak. 4) Sebagian besar anak belum memahami etika, moral secara sederhana.

Mayoritas penduduk Indonesia beragama Islam. Islam telah mengajarkan nilai-nilai positif yang bermanfaat dalam kehidupan bermasyarakat. Tetapi kondisi saat ini sangat memprihatinkan, dimana tanda-tanda kehancuran suatu bangsa sudah terlihat pada bangsa Indonesia. Menurut Dr. Thomas Lickona bahwa ada 10 (sepuluh) tanda dari perilaku manusia yang menunjukan arah kehancuran suatu bangsa, yaitu: 1) Meningkatnya kekejaman di kalangan remaja, 2) Ketidakjujuran yang membudaya, 3) Semakin tingginya rasa tidak khidmat kepada orang tua, guru, dan pemimpin, 4) Pengaruh peer group terhadap tindakan kekejaman, 5) Meningkatnya keraguan dan kedengkian, (6) Penerapan bahasa yang memburuk, 7) Pengurangan etos kerja, 8) Berkurangnya rasa tanggung jawab individu dan warga Negara, 9) Memuncaknya perilaku merusak diri, 10) Semakin kaburnya pedoman moral(Inawati, 2017). Pendidikan moral diberikan di berbagai macam lembaga pendidikan, salah satunya di lembaga Pendidikan Anak Usia Dini (PAUD). PAUD atau usia pra sekolah adalah masa di mana anak belum memasuki pendidikan formal. PAUD merupakan basis 
penciptaan karakter anak usia dini, sehingga tercorak perilaku dan kemampuan dasar yang sesuai perkembangannya agar seterusnya dapat sebagai warga negara baik. Untuk itu diperlukan penanaman nilai-nilai moral pada anak usia dini. Pentingnya penanaman nilai-nilai moral pada anak usia dini agar karakter anak dapat berkembang dengan potensi dan kemampuan anak secara optimal serta tumbuhnya sikap dan perilaku positif bagi anak(Yuliana, 2015).

Tujuan dari alat permainan edukatif sebagai sumber belajar anak-anak RA ataupun TK agar mereka mendapatkan pengalaman belajar. Pengetahuan ini bakal berguna untuk meningkatkan aspek-aspek perkembangan anak TK/RA. Alat Permainan Edukatif (APE) adalah segala sesuatu yang dapat digunakan sebagai sarana atau alat permainan yang mengandung nilai pendidikan dan dapat mengembangkan seluruh aspek kemampuan anak(Hijriati, 2016). Aktualisasi nilai moral pada anak usia dini berbagai metode yang dapat dipakai oleh pendidik. Akan tetapi, sebelum memastikan dan menerapkan metode yang ada perlu diketahui bahwa pendidik harus menginterpretasikan berbagai metode yang akan dipakai, karena ini akan berpengaruh terhadap maksimal tidaknya keberhasilan penanaman nilai moral tersebut. Cara dalam penanaman nilai moral kepada anak usia dini sangatlah bervariasi, diantaranya bercerita, bernyanyi, bermain, bersajak dan karya wisata(Murdiono, n.d.).Untuk menciptakan dan mengarahkan seseorang menjadi lebih bermoral maka diperlukanlah pendidikan moral, dengan pendidikan moral pada anak usia dini dimaksudkan supaya manusia belajar sebagai manusia yang berakhlakul karimah. Yang dimaksud dengan pendidikan moral adalah: suatu program pendidikan (sekolah dan luar sekolah) yang mengorganisasikan dan "menyederhanakan" sumber-sumber moral dan disajikan dengan memperhatikan pertimbangan psikologis untuk tujuan pendidikan(Sapdiani et al., 2018).

\section{B. Pembahasan}

\section{Alat Permainan Edukatif}

Alat permainan edukatif sebagai segala sesuatu yang dapat digunakan sebagai sarana atau peralatan untuk bermain yang mengandung nilai edukatif dan dapat mengembangkan seluruh 
kemampuan anak. Setiap anak yang dilahirkan di muka bumi ini memerlukan pendidikan. Pendidikan yang dilakukan harus diawasi dan dipelihara secara terus menerus sebagai bentuk pelatihan dasar dalam membentuk sikap dan kebiasaan agar anak memiliki kemungkinan untuk berkembang secara wajar dan optimum dalam setiap tahap perkembangannya dalam kehidupan di masa datang(Sapendi, 2015). Permainan edukatif merupakan permainan yang mempunyai unsur mendidik diperoleh dari sesuatu yang ada dan merekat serta sebagai bagian dari permainan itu sendiri. Permainan yaitu sebuah aktivitas rekreasi dengan tujuan bersenang-senang, mengisi waktu luang, atau berolahraga ringan, permainan biasanya dilakukan sendiri atau bersama-sama(Bataha, 2017). Oleh sebab itu, perhatian terhadap penyelenggaraan Pendidikan Anak Usia Dini (PAUD) perlu mendapat perhatian yang serius. Persoalannya ialah bahwa penyelenggaraan pendidikan anak usia dini masih banyak yang belum memenuhi standar mutu yang sesuai. Salah satu penyebabnya adalah bahwa masih terbatasnya Alat Permainan Edukatif (APE) yang digunakan oleh pendidikan dalam pelaksanaan pembelajaran(Solfema et al., 2018).

Menurut Heliyantini Soetopo dalam(Pramuditya, 2016): Menyikapi perkembangan pendidikan bagi kelompok usia dini dan berbagai konsep memakai alat bantu ajar serta strategi dalam merealisasikan pelaksanaan kegiatan belajar mengajar baik di kelas/ indoor maupun di luar kelas/ outdoor, membutuhkan dinamika serta daya kreativitas agar guru dan anak terus memiliki pengalaman baru serta tidak merasa jenuh dalam melakukan kegiatan di ruang kelas. Salah satu alat permainan yang biasa digunakan di PAUD adalah Alat Permainan Edukatif (APE). Alat permainan edukatif adalah semua jenis perminan yang bertujuan untuk menciptakan lingkungan dan jenis permainan yang bersifat edukatif dari kepentingan peserta didik (anak)(Muazzomi, 2017). Dalam Penanaman nilai agama dan moral alat permainan edukatif yang digunakan berbahan dasar dari kardus yang dibuat rapi sehingga aman digunakan untuk memnetukan waktu sholat jam yang digunakan menunjukkan waktu sholat telah tiba. Hal ini dikaitkan agar anak belajarnya lebih semangat dalam menjalankan ibadahnya. Nilai-nilai agama dan moral yang ditanamkan melalui pembiasaan salah satunya yaitu berdo'a. Sedangkan Syamsuardi 
berpendapat bahwa permainan edukatif adalah semua bentuk permainan yang dirancang untuk memberikan pengalaman pendidikan atau pengalaman belajar kepada para pemainnya, termasuk permainan tradisional dan moderen yang diberi muatan pendidikan danpengajaran. Sumiyati mengutip dalam bukunya pendidikan anak usia dini dalam Islam, memfokuskan bahwa anak-anak secara aktif menyusun pengetahuan mereka, anak-anak memiliki konsep yang lebih logis, sistematis, dan rasional sebagai akibat dari interaksi anak dengan orang lain. Anak usia dini ialah wujud individu yang sedang menjalani suatu proses perkembangan dengan pesat dan mendasar bagi kehidupan selanjutnya (Putra Made, Komang Dewi Sukaryasih, 2016).

\section{Nilai Agama}

Pengertian nilai-nilai agama Islam adalah pertama, yang dimaksud nilai dalam Kamus Purwadarminta adalah: a). harga dalam arti taksiran, b). harga sesuatu, c). angka kepandaian, d). kadar, mutu, e). ciri-ciri yang penting atau berguna bagi kemanusiaan.

Agama sangat berperan dalam pembentukan perilaku anak, sehingga pembentukan pribadi anak akan membaur sesuai pertumbuhan dan perkembangan anak. Sehingga diperlukan pendidikan dengan persyaratanpersyaratan tertentu dan pengawasan serta pemeliharaan yang terus-menerus(Sapendi, 2015). Secara umum tujuan peningkatan nilai agama pada diri anak adalah meletakkan dasar-dasar keimanan dengan pola takwa kepada-Nya dan keindahan akhlak, cakap, percaya pada diri sendiri, serta memiliki kesiapan untuk hidup di tengahtengah dan bersama-sama dengan masyarakat untuk menempuh kehidupan yang diridhai-Nya (Ananda, 2017). Mengenai tujuan khusus peningkatan nilai agama pada anakanak usia dini yaitu: a. Meningkatkan 'rasa iman dan cinta terhadap Tuhan, b. Membiasakan anak-anak agar melakukan ibadah kepada Tuhan, c. Membiasakan supaya perilaku dan sikap anak didasari dengan nilai-nilai agama, d. Membantu anak agar tumbuh dan berkembang menjadi pribadi yang beriman dan bertaqwa terhadap Tuhan(Trimuliana et al., 2019).

Pendidikan agama menekankan pada pemahaman tentang agama serta bagaimana agama diamalkan diaplikasikan dalam kehidupan sehari-hari. Penanaman nilai-nilai agama tersebut 
disesuaikan dengan tahapan perkembangan anak serta keunikan yang dimiliki oleh setiap anak(Nurwita, 2019). Islam meneladankan nilai-nilai keislaman dengan metode pembiasaan ibadah, contohnya puasa, shalat lima waktu, dan sebagainya. Agama merupakan suatu yang dimiliki oleh setiap individu (anak) melalui perpaduan antara potensi bawaan sejak lahir dengan pengaruh dari luar individu. Sedangkan menurut Permendiknas No 58 Tahun 2009 yang menyangkut tentang nilai-nilai agama dan moral adalah mengenai landasan filosofis dan religi Pendidikan dasar anak usia dini, pada dasarnya harus berdasarkan pada nilai-nilai filosofis dan religi yang dipegang oleh lingkungan yang berada disekitar anak dan agama yang dianutnya(Kusnilawati et al., 2018). Dalam rangka memelihara dan menumbuhkan potensi anak usia dini perlu memilih cara yang tepat. Untuk itulah pendidik TK/RA harus pandai dalam memilih dan menentukan cara yang akan digunakan untuk menanamkan nilai-nilai agama anak agar pesan moral yang ingin disampaikan pendidik dapat benar-benar sampai dan dipahami oleh anak untuk bekal kehidupannya di masa depan. Pemahaman yang dimiliki guru atau pendidik akan mempengaruhi keberhasilan menanaman nilai-nilai agama anak secara optimal(Amiruddin, 2016). Internalisasi nilai agama merupakan hal yang penting dilakukan dalam suatu lembaga pendidikan. Internalisasi nilai agama merupakan hal yang urgen dan harus terjadi karena dalam internalisasi nilai agama terdapat hubungan timbal balik antara pendidik dan peserta didik (Rifa'i, 2016).

\section{Nilai Moral}

Pengertian moral dalam (Ananda, 2017) adalah ukuran baik-buruknya seseorang, baik dalam pribadi maupun sebagai warga masyarakat, dan warga negara. Sedangkan pendidikan moral adalah pendidikan untuk menjadikan anak manusia bermoral dan manusiawi. Sedangkan menurut Ouska dan Whellan, moral adalah prinsip baik-buruk yang ada dan melekat dalam diri individu/seseorang. Sekalipun moral itu berada dalam diri individu, tetapi moral berada dalam suatu sistem yang berwujud aturan. Moral dan moralitas memiliki sedikit perbedaan, karena moral adalah prinsip baik-buruk sedangkan moralitas merupakan kualitas pertimbangan baikburuk(Khaironi, 2017). Dalam pelaksanaan penanaman nilai 
moral pada anak usia dini banyak metode yang dapat digunakan oleh guru atau pendidik. Namun sebelum memilih dan menerapkan metode yang ada perlu diketahui bahwa guru atau pendidik harus memahami metode yang akan dipakai, karena ini akan berpengaruh terhadap optimal tidaknya keberhasilan penanaman nilai moral tersebut. Metode dalam penanaman nilai moral kepada anak usia dini sangatlah bervariasi, diantaranya bercerita, bernyanyi, bermain, bersajak dan karya wisata(Murdiono, n.d.).

Pendidikan moral diberikan di berbagai macam lembaga pendidikan, salah satunya di lembaga Pendidikan Anak Usia Dini (PAUD). PAUD atau usia pra sekolah adalah masa di mana anak belum memasuki pendidikan formal. PAUD merupakan basis pembentukan karakter moral manusia, sehingga terbentuk perilaku dan kemampuan dasar sesuai dengan tahap perkembangannya agar selanjutnya dapat menjadi warga negara yang baik. Untuk itu diperlukan penanaman nilai-nilai moral pada anak usia dini. Pentingnya penanaman nilai-nilai moral pada anak usia dini agar karakter anak dapat berkembang dengan potensi dan kemampuan anak secara optimal serta tumbuhnya sikap dan perilaku positif bagi anak(Yuliana, 2015). Untuk menciptakan dan mengarahkan seseorang menjadi lebih bermoral maka diperlukanlah pendidikan moral, dengan pendidikan moral dimaksudkan agar manusia belajar menjadi manusia yang bermoral. Yang dimaksud dengan pendidikan moral adalah: suatu program pendidikan (sekolah dan luar sekolah) yang mengorganisasikan dan "menyederhanakan" sumber-sumber moral dan disajikan dengan memperhatikan pertimbangan psikologis untuk tujuan pendidikan(Sapdiani et al., 2018).

\section{Metode}

Penelitian yang dilakukan di RA. Al Musthofa Bangsal yaitu penelitian tindakan kelas (classroom action research), yang dilaksanakan di dalam kelas pada setiap siklus perencanaan, pelaksanaan tindakan, observasi,evaluasi (Arikunto, 2006). Prosedur dan desain penelitian harus diketahui bahwa pada hakekatnya adalah dalam rangka peningkatan mutu hasil pembelajaran secara konsisten dari awal hingga akhir yang dilakukan secara kolaboratif antara peneliti dan teman sejawat. Populasi yang digunakan adalah murid RA Al Musthofa Bangsal 
Kabupaten Mojokerto. Sampel yang digunakan stratified random sampling. Teknik pengumpulan data yaitu menggunakan observasi, penilaian dan dokumentasi.

Tabel. 1 Kisi-kisi Instrumen Penelitian Penanaman Nilai Agama dan Moral

\begin{tabular}{|c|c|c|c|}
\hline Variabel & Indikator & $\begin{array}{c}\text { Aspek } \\
\text { pengamatan }\end{array}$ & Item \\
\hline \multirow{5}{*}{$\begin{array}{l}\text { Penanaman } \\
\text { Nilai } \\
\text { Agama dan } \\
\text { Moral }\end{array}$} & Doa-doa & $\begin{array}{c}\text { Doa sebelum } \\
\text { dan sesudah } \\
\text { belajar }\end{array}$ & 1 \\
\hline & \multirow{2}{*}{$\begin{array}{c}\text { Merawat } \\
\text { Makhluk } \\
\text { Ciptaan } \\
\text { Tuhan }\end{array}$} & $\begin{array}{c}\text { Tanaman } \\
\text { sebagai ciptaan } \\
\text { Tuhan }\end{array}$ & 2 \\
\hline & & $\begin{array}{c}\text { Binatang } \\
\text { sebagai ciptaan } \\
\text { Tuhan }\end{array}$ & 3 \\
\hline & \multirow{2}{*}{$\begin{array}{l}\text { Bersyukur } \\
\text { terhadap } \\
\text { lingkungan }\end{array}$} & Teman & 4 \\
\hline & & Guru & 5 \\
\hline
\end{tabular}

Sumber: Panduan Penilaian perkembangan nilai agama dan moral pada kelompok anak usia 5-6 tahun kementrian pendidikan dan kebudayaan direktorat jenderal pendidikan anak usia dini dan pendidikan masyarakat 2018, p. 18

Tabel 2 Klasifikasi Skala Penilaian Tingkat Keberhasilan Belajar

\begin{tabular}{cll}
\hline $\begin{array}{c}\text { Tingkat } \\
\text { Keberhasilan } \\
(\%)\end{array}$ & \multicolumn{1}{c}{ Kriteria } & \multicolumn{1}{c}{ Keterangan } \\
\hline $90-100 \%$ & $\begin{array}{l}\text { BSB : Berkembang } \\
\text { Sangat Baik }\end{array}$ & $\begin{array}{l}\text { BSB = Bintang empat } \\
(4)\end{array}$ \\
\hline $70-89 \%$ & $\begin{array}{l}\text { BSH : Berkembang } \\
\text { Sesuai Harapan }\end{array}$ & BSH = Bintang tiga (3) \\
\hline $50-69 \%$ & MB : Mulai Berkembang & MB = Bintang dua (2) \\
\hline $0-49 \%$ & BB : Belum Berkembang & BB = Bintang satu (1) \\
\hline
\end{tabular}

Sumber: Muhammad Fadhillah, Desain Pembelajaran PAUD (Fadillah, 2012). 


\section{Hasil Penelitian}

Hasil Penelitian dari pelaksanaan alat permainan edukatif dalam menanamkan nilai Agama dan moral pada siklus I dilaksanakan dengan tema/sub tema rekreasi/kereta api, pada siklus II dilaksnakan dengan tema/sub tema Alat Komunikasi/telepon. Pada siklus I dan siklus II dilakukan dengan tema/sub tema yang berbeda. Siklus I dilakukan 3 kali pertmuan karena dirasa belum mecapai ketuntasan maka dilaksanakan siklus IIdengan 3 kali pertemuan. Kegiatan ini diawali oleh guru dengan fase menyampaikan tema/sub tema. Dalam fase ini guru memberikan apresiasi dengan bertanya kepada anak didik tentang tema apa sekarang? Sub temanya apa?" langkah berikutnya anak menjawab tema rekreasi bu sub tema kereta api. Disinilah guru memberi pengarahan apa yang akan dilakukan pada pembelajaran penanaman nilai agama dan moral melalui alat permainan edukatif.

Pada kegiatan inti terdapat tiga fase utama yang dilakukan. Fase mendemonstrasikan keterampilan (pengetahuan procedural). Anak mendengarkan penjelasan guru sambil menyimak media yang digunakan. Penjelasan lain dari guru, berupa mengingatkan kepada anak bahwa mengenal huruf dengan media papan flanel yakni dengan mencari potonganpotongan huruf yang ada diwada terus di tempel dan disusun menjadi kalimat seperti contoh. Disini guru memberikan contoh gambar dan tulisan kalimat sehingga anak lebih muda dalam menyusun dan membedakan huruf. Anak memperhatikan guru mendemonstrasikan cara mengenal mencari huruf dalam wadah dan menempel dipapan flanel. Setelah itu anak di tanya oleh guru sambil guru membawah gambar, kalau boleh tau ini huruf apa ya? Dan ini huruf apa? Maka anak akan menggigat huruf yang ada dalam gambar dan dapat mempraktekkan dengan muda.

Pada fase membimbing pembelajaran, anak di suruh maju satu persatu untuk memperaktekkan menempel huruf demi huruf di papan flanel. Guru memberikan pengarahan kepada anak dan bertanya kepada anak jika ada yang belum diketahui. Langkah berikutnya yang dilakukan guru mengajak anak untuk memperhatikan setiap warna dari huruf-huruf flanel tersebut. Guru menempelkan gambar kereta api di papan flanel agar anak muda mengigat setiap huruf yang ada. Fase mengecek pemahaman dan memberikan umpan balik yang dilakukan guru 
denga recalling posisi melingkar dengan menanyakan kepada anak tadi bu guru membawah gambar apa? Tadi huruf apa saja?"disini guru akan mengetahui anak yang paham akan pembelajaran mengenal huruf vokal dan konsonan melalui media papan flanel. Pada tahap ini, peneliti melakukan evaluasi tentang pelaksanaan pembelajaran dengan Alat permainan Edukatif. Dalam pembelajaran menggunakan alat peermainan edukati dalam menanamkan nilai Agama dan Moral pada siklus I Pertemuan Pertama,kedua dan ketiga, dengan pengamat untuk mengetahui kekurangan dan mengatasi hambatan yang dihadapi penelti selama proses pembelajaran, data yang terkumpul menunjukkan bahwa pelaksanaan pembelajaran pada siklus I Pertemuan pertama,kedua dan ketiga terlaksana baik, namun pengamat memberikan masukan agar pelaksanaan pembelajaran lebih baik lagi.

Pada siklus II diawali dengan perencanaan tema/sub tema, penyambutan kedatangan siswa, pembukaan Outdoor, kegiatan pagi meliputi religi dan materi pagi, break time, kompetensi dasar, indikator, alat dan bahan/ media yang digunakan, kegiatan akhir dan teknik penilaian. Kemudian pelaksanaan diawali dengan fase menyampaikan tema dan sub tema. Dalam fase ini guru memberikan apresiasi dengan bertanya kepada anak didik tentang tema apa sekarang? Sub temanya apa?" langkah berikutnya anak menjawab tema Alat Komunikasi bu sub tema Telepon. Disinilah guru memberi pengarahan apa yang akan dilakukan pada pembelajaran menanamkan niali agama dan moral melalui alat permainan edukatif.

Pada kegiatan inti terdapat tiga fase utama yang dilakukan. Fase mendemonstrasikan keterampilan (pengetahuan procedural). Anak mendengarkan penjelasan sambil menyimak media yang digunakan. Penjelasan lain dari guru, berupa mengingatkan kepada anak bahwa penanaman nilai agama dan moral dengan alat permainan edukatif yakni dengan mencari potongan-potongan huruf yang ada di wadah terus di tempel dan disusun menjadi kalimat seperti contoh. Disini guru memberikan contoh real telepon mainan dan tulisan kalimat di papan tulis sehingga anak lebih muda dalam menyusun dan membedakan huruf. Anak memperhatikan guru mendemonstrasikan cara mengenal alat permainan edukatif yaitu papan flanel. Setelah itu anak di tanya oleh guru sambil guru membawah Telepon Mainan, kalau boleh tau ini huruf apa 
ya? dan ini huruf apa? Maka anak akan menggigat huruf yang diperaktekkan guru sehingga anak mempraktekkan dengan mudah.

Pada fase membimbing pembelajaran, anak di suruh maju satu persatu untuk memperaktekkan menempel huruf demi huruf di papan flanel. Guru memberikan pengarahan kepada anak dan bertanya kepada anak huruf ini mengadung nilai ibadah sedangkan huruf yang lain berkaitan dengan nilai moral jika ada yang belum diketahui. Langkah berikutnya yang dilakukan guru mengajak anak untuk memperhatikan setiap huruf-huruf flanel yang dikasih inisial tersebut. Guru menempelkan Huruf-huruf di papan flanel agar anak muda mengigat setiap huruf yang ada. Fase mengecek pemahaman dan memberikan umpan balik yang dilakukan guru dengan recalling posisi melingkar dengan menanyakan kepada anak tadi bu guru membawah benda apa in? Tadi huruf apa saja?"disini guru akan mengetahui anak yang paham akan pembelajaran penanaman nilai agama dan moral melalui alat permainan edukatif belajar sholat. Observasi awal dilakukan untuk mengidentifikasi pokok permasalahan pada penelitian ini. Peneliti sebagai guru kelas juga mempersiapkan perangkat pembelajaran dan instrumen untuk menunjang penelitian ini yang berlangsung dalam 2 siklus. Berdasarkan hasil penelitian pada siklus I dan II diperoleh temuan-temuan sebagai berikut. 
Tabel 3. Instrumen penilaian Siklus

\begin{tabular}{|c|c|c|c|c|c|c|c|c|c|c|c|c|c|}
\hline \multirow{2}{*}{ No } & \multirow{2}{*}{$\begin{array}{c}\text { Kompetensi } \\
\text { dasar (KD) }\end{array}$} & \multirow{2}{*}{$\begin{array}{l}\text { Aspek yang diamati } \\
\text { (sub Indikator) }\end{array}$} & \multicolumn{11}{|c|}{ Nama Anak } \\
\hline & & & & $\begin{array}{l}\mathrm{A} \\
\mathrm{z}\end{array}$ & $\begin{array}{l}\mathrm{B} \\
\mathrm{r}\end{array}$ & $\begin{array}{l}\mathrm{B} \\
\mathrm{m}\end{array}$ & $\begin{array}{l}\mathrm{C} \\
1\end{array}$ & $\begin{array}{ll}D & F \\
v & t\end{array}$ & $\begin{array}{ll}F & I \\
t & d\end{array}$ & $\begin{array}{l}\mathrm{N} \\
\mathrm{y}\end{array}$ & $\begin{array}{l}\mathrm{N} \\
\mathrm{d}\end{array}$ & $\begin{array}{l}\mathrm{Y} \\
\mathrm{s}\end{array}$ & $\begin{array}{l}\mathrm{Z} \\
\mathrm{h}\end{array}$ \\
\hline 1 & $\begin{array}{l}\text { Melafalkan } \\
\text { Doa-doa } \\
\text { sehari-hari }\end{array}$ & $\begin{array}{l}\text { Doa sebelum dan } \\
\text { sesudah belajar }\end{array}$ & 4 & 3 & 4 & 3 & 3 & 43 & 33 & 3 & 4 & 3 & 2 \\
\hline 2 & $\begin{array}{l}\text { Merawat } \\
\text { Makhluk } \\
\text { Ciptaan } \\
\text { Tuhan dalam } \\
\text { kehidupan } \\
\text { sehari-hari }\end{array}$ & $\begin{array}{l}\text { Tanaman sebagai } \\
\text { ciptaan Tuhan }\end{array}$ & & 4 & 4 & 4 & 3 & 43 & 34 & 3 & 4 & 3 & 2 \\
\hline \multirow[t]{7}{*}{3} & $\begin{array}{l}\text { Bersyukur } \\
\text { terhadap } \\
\text { lingkungan } \\
\text { yang ada }\end{array}$ & $\begin{array}{l}\text { Binatang sebagai } \\
\text { ciptaanTuhan }\end{array}$ & 3 & 3 & 3 & 3 & 3 & 43 & 34 & 3 & 4 & 3 & 3 \\
\hline & & Teman & 4 & 4 & 4 & 4 & 3 & 33 & 4 & 3 & 4 & 3 & 2 \\
\hline & & Guru & 4 & 3 & 4 & 4 & 3 & 43 & 34 & 3 & 4 & 3 & 2 \\
\hline & KKM & $\begin{array}{l}\mathrm{T} \\
\mathrm{TT} \\
\end{array}$ & $\sqrt{ }$ & & $\sqrt{ }$ & $\sqrt{ }$ & $\sqrt{ }$ & $\sqrt{ } \sqrt{ }$ & $\sqrt{ }$ & $\sqrt{ }$ & $\sqrt{ }$ & $\sqrt{ }$ & $\sqrt{ }$ \\
\hline & & & 1 & 1 & 1 & 1 & 7 & 17 & 1 & 7 & 1 & 7 & 5 \\
\hline & & & 0 & 0 & 0 & 0 & 5 & 05 & 50 & 5 & 0 & 5 & 0 \\
\hline & Jumlah & & 0 & 0 & 0 & 0 & & 0 & 0 & & 0 & & \\
\hline & Total & & \multicolumn{11}{|c|}{1050} \\
\hline & Rata-rata & & \multicolumn{11}{|c|}{88} \\
\hline & $\begin{array}{l}\text { Presentase } \\
\text { Ketuntasan }\end{array}$ & & \multicolumn{11}{|c|}{$91 \%$} \\
\hline & Jumlah T & & \multicolumn{11}{|c|}{11} \\
\hline & Jumlah TT & & \multicolumn{11}{|c|}{1} \\
\hline
\end{tabular}

a. Keterlaksanaan Pembelajaran

Selama berlangsungnya pembelajaran peneliti dan teman seperjuangan menggunakan observasi yang mengobservasi tindakan yang dilakukan anak yakni ada poin-poinnya yang berisikan usaha yang dilakukan anak, ekspresi dalam pembelajaran, dan kemampuan dalam pembelajaran yang di peroleh pada siklus I dan II, alhamdulillah banyak peningkatan.

b. Hasil belajar anak

Berikut ini akan disajikan data hasil belajar anak pada pembelajaran terkait nilai agama dan moral melalui alat permainan edukatif pada siklus I dan II.

Tabel 4 Klasifikasi Skala Penilaian Tingkat Keberhasilan Belajar

\begin{tabular}{ccccccccc}
\hline & & \multirow{2}{*}{ Pra } & \multicolumn{3}{c}{ Siklus I } & \multicolumn{3}{c}{ Siklus II } \\
No & Nama & siklus & Pert. & Pert. & Pert. & Pert. & Pert. & Pert. \\
& & & $\mathbf{1}$ & $\mathbf{2}$ & $\mathbf{3}$ & $\mathbf{1}$ & $\mathbf{2}$ & $\mathbf{3}$ \\
\hline 1 & AB & 40 & 50 & 50 & 50 & 50 & 75 & 100 \\
2 & AZ & 45 & 75 & 75 & 75 & 75 & 100 & 100 \\
3 & BR & 25 & 50 & 75 & 75 & 75 & 75 & 100
\end{tabular}


@ ThufuLA: Jurnal Inovasi Pendidikan Guru Raudhatul Athfal | 107

\begin{tabular}{|c|c|c|c|c|c|c|c|c|}
\hline 4 & B & 25 & 50 & 75 & 75 & 75 & 75 & 100 \\
\hline 5 & CL & 30 & 50 & 50 & 75 & 75 & 75 & 75 \\
\hline 6 & DV & 55 & 75 & 75 & 75 & 100 & 100 & 100 \\
\hline 7 & FT & 40 & 50 & 50 & 50 & 75 & 75 & 75 \\
\hline 8 & ID & 30 & 50 & 50 & 50 & 50 & 75 & 100 \\
\hline 9 & $\mathrm{NY}$ & 35 & 50 & 50 & 50 & 50 & 50 & 75 \\
\hline 10 & ND & 50 & 75 & 75 & 75 & 75 & 100 & 100 \\
\hline 11 & YS & 25 & 50 & 50 & 50 & 50 & 50 & 75 \\
\hline 12 & $\mathrm{ZH}$ & 30 & 50 & 50 & 50 & 50 & 50 & 50 \\
\hline \multicolumn{2}{|c|}{ Jumlah } & 430 & 675 & 725 & 750 & 800 & 900 & 1050 \\
\hline \multicolumn{2}{|c|}{ Rata-Rata } & 36 & 56 & 60 & 63 & 67 & 75 & 88 \\
\hline \multicolumn{2}{|c|}{ Persentase } & & 25 & 25 & 25 & 25 & 25 & 25 \\
\hline
\end{tabular}

Hasil penelitian diatas menunjukan bahwa perkembangan anak dalam menerapkan alat permainan edukatif, sesuai dengan kepribadian anak yang unik, bermain merupakan dunia anak dan merupakan kebutuhan baginya. Dengan perkembangan anak dalam menerapkan alat permainan edukatif dinilai sangat tepat dalam peningkatan kemampuan kognitif anak. Hal ini sesuai dengan pendapat Broove, bahwa media dapat diartikan sebagai alat yang berfungsi untuk menyampaikan pesan pembelajaran(Sanaky Hujair, 2013). Pada anak usia dini setidaknya terdapat lima aspek perkembangan yang harus dikembangkan untuk menunjang tumbuh kembang anak menjadi optimal, antara lain Perkembangan Fisik, Motorik Kasar, Motorik Halus, Bahasa, Sosial, dan Emosi.menstimulasi lima aspek perkembangan ini dapat dilakukan dengan berbagai cara salah satunya adalah bermain dengan menggunakan alat permainan edukatif(Prilya Shanty Andrianie1, Rosita Yuniati2, 2018).

Penerapan alat permainan edukatif dalam menanamkan nilai-nilai agama dan moral di Raudhatul Athfal Al Musthofa Bangsal Mojokerto. Pelaksanaan kegiatan penelitian berlangsung selama 2 siklus, yaitu sklus I dan siklus II, dimana tiap siklus terdiri dari 3 pertemuan. Dalam pelaksanaan penelitian ini setiap pertemuan terbagi dalam tiga tahap kegiatan yaitu kegiatan awal, kegiatan inti dan kegiatan penutup. 


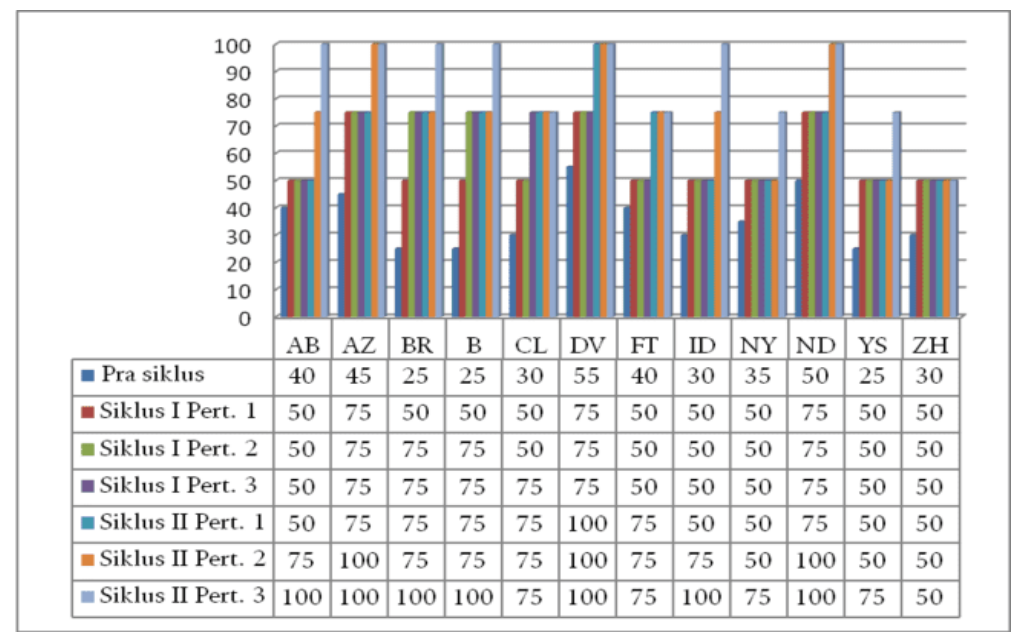

Gambar 1. Rekapitulasi APE dalam menanamkan nilai Agama dan Moral AUD Pra Siklus, Siklus I dan Siklus II

Berdasarkan tabel 3 dan gambar 1 di atas, maka dapat diketahui Alat permainan edukatif dalam menanamkan nilai Agama dan Moral pada Raudhatul Athfal Al Musthofa Bangsal rata-rata hasil belajar anak-anak melalui Observasi dari siklus I dan II mengalami ketuntasan belajar kelasikal yaitu pada siklus I pertemuan pertama di peroleh nilai rata-rata anak 52 dengan ketuntasan 25\%. Pada siklus I pertemuan kedua nilai rata-rata anak 61 dengan ketuntasan 42\%. Pada siklus I pertemuan ketiga nilai rata-rata anak 63 dengan ketuntasan 50\%. Untuk siklus II pertemuan pertama nilai rata-rata anak 67 dengan ketuntasan58\%. Dan pada siklus II pertemuan kedua nilai ratarata anak 75 dengan ketuntasan $75 \%$. Sedangkan pada siklus II pertemuan ketiga nilai rata-rata anak 88 dengan ketuntasan 91\% Berkembang sangat Baik (BSB). 
$\cong \quad$ ThufuLA: Jurnal Inovasi Pendidikan Guru Raudhatul Athfal | 109

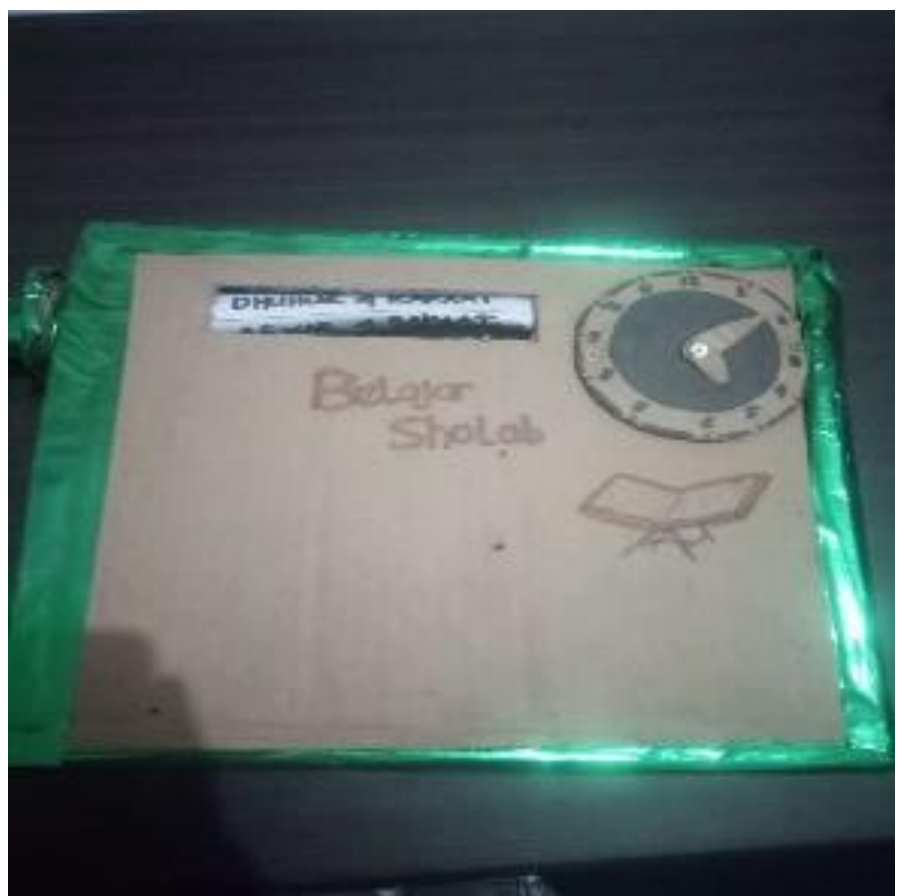

Gambar 2. Alat permainan Edukatif

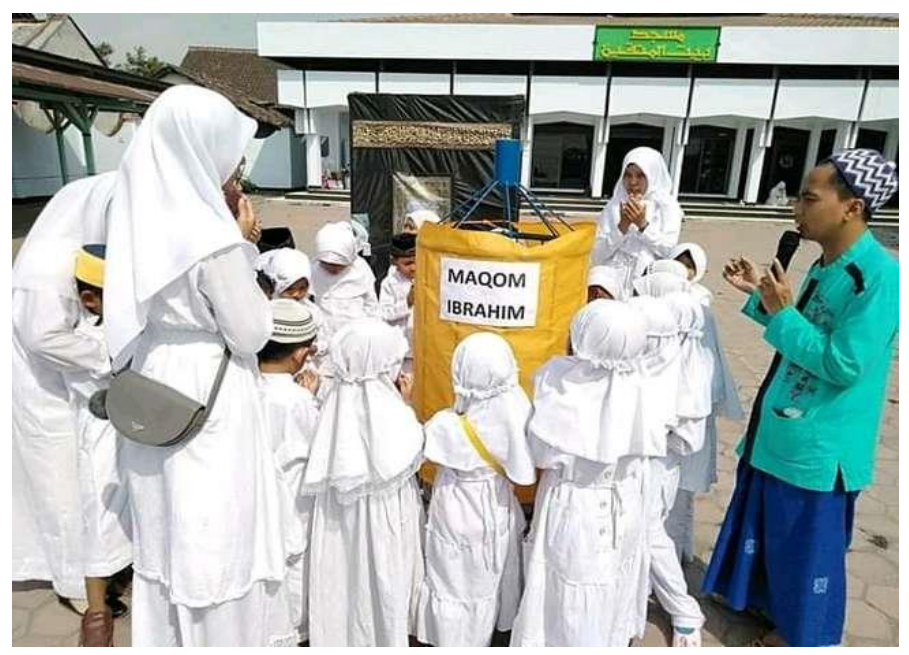

Gambar 3. Penanaman Nilai Agama dan moral 


\section{Simpulan}

Penelitian di Raudhatul Athfal Al Musthofa Bangsal Kabupaten Mojokerto memberikan dampak positif pada perkembangan anak usia dini sebelum diberikan alat permainan edukatif didapatkan kriteria belum berkembang sangatlah banyak berdasarkan hasil observasi di lapangan. Sesudah diberikan alat permainan edukatif mengalami peningkatan perkembangan dari kriteria belum berkembang (BB) menjadi kriteria berkembang sangat baik(BSB) dengan nilai ketuntasn 91\% yang menunjukkan bahwa hasil tersebut sudah baik. Ada peran penting dari alat permainan edukatif terhadap aspek perkembangan anak sebelum dan sesudah pemberian stimulasi. Pelaksanaan pembelajaran menggunakan alat permainan edukatif pada siklus I dan II di lihat dari tabel Observasi anakanak meningkat diketahui dari usaha yang dilakukan anak ada peningkatan dalam penenaman nilai agama dan moral anak menggunakan alat permainan edukatif dan kemampuan anak dalam pembelajaran penanaman nilai itu bias berkembang sangat baik.

\section{Referensi}

Amalia, R. R. (2013). Terapi Bermain Bagi Anak Tunarungu. INSANIA: Jurnal Pemikiran Alternatif Kependidikan, 18(2), 231-243.

Ardha, R. Y. (2017). Keterampilan Sosial Anak Tunagrahita Ringan Di Sekolah Dasar Inklusi. JASSI ANAKKU, 18(2), 4650.

Astiti, Y. W. (2016). Peningkatan Kemampuan Persepsi Bunyi Menggunakan Media Audio Keyboard Pada Anak Tunarungu Kelas 1 Sekolah Dasar Di SLB Negeri Sragen. Widia Ortodidaktika, 5(8), 839-852.

Bekti Agustiningrum, M. D. (n.d.). Penanaman Proses

Pendisplinan Diri Anak Berkebutuhan Khusus (Tuna Rungu Wicara) dalam Pembelajaran Tari Tradisional. Cakrawala Dini, 5(1), 240619.

Brownell, M. T., Jones, N. D., Sohn, H., \& Stark, K. (2020).

Improving teaching quality for students with disabilities:

Establishing a warrant for teacher education practice.

Teacher Education and Special Education, 43(1), 28-44. Cano, S., Peñeñory, V., Collazos, C. A., \& Albiol-Pérez, S. (2020). 
Designing internet of tangible things for children with hearing impairment. Information, 11(2), 70.

Chadha, S., \& Cieza, A. (2017). Promoting global action on hearing loss: World hearing day. Taylor \& Francis.

Darmono, A. (2015). Peran Orang Tua Dalam Pendidikan Anak Berkebutuhan Khusus. Al-Mabsut: Jurnal Studi Islam Dan Sosial, 9(1), 141-161.

Davisa, A. C., \& Hoffmanb, H. J. (2019). Hearing loss: rising prevalence and impact. Bull World Health Organ, 97, 646646A.

Desalew, A., Feto Gelano, T., Semahegn, A., Geda, B., \& Ali, T. (2020). Childhood hearing impairment and its associated factors in sub-Saharan Africa in the 21st century: A systematic review and meta-analysis. SAGE Open Medicine, 8, 2050312120919240.

DI SLB, B. K. (n.d.). Pembelajaran Bahasa Melalui Metode Maternal Reflektif (Mmr) Untuk Anak Tunarungu Kelas Dasar Iii.

Djurayeva, S. (2020). The development of speech activity in children with hearing impairment. Архив Научных Публикаций JSPI.

Effendy, P. A., Sihkabuden, S., \& Husna, A. (2019). Penerapan Kurikulum 2013 di SDLBK Bhakti Luhur Malang pada Kelas B (Tunarungu). Jurnal Kajian Teknologi Pendidikan, 1(3), 213-220.

Elshaiekh, N. E. M., Idris, B. Y. M., \& Hussein, M. A. (2013). Multimedia Education System for Deaf and Hear Impairment Children. The InternationalArab Conference on Information Technology.

Firmansyah, I., \& Widuri, E. L. (2014). Subjective well-being pada guru sekolah luar biasa (SLB). Universitas Ahmad Dahlan.

Hearing, J. C. on I. (2007). Year 2007 position statement: Principles and guidelines for early hearing detection and intervention programs. Pediatrics, 120(4), 898-921.

Heriyansyah, H. (2018). Guru Adalah Manajer Sesungguhnya Di Sekolah. Islamic Management: Jurnal Manajemen Pendidikan Islam, 1(01).

Hernawati, T. (2007). Pengembangan kemampuan berbahasa dan berbicara anak tunarungu. Jurnal JASSI_anakku, 7(1), 101-110. 
Hutami, P. A., Ajisuksmo, C. R. P., \& Tunjungsari, H. (2014). GAMBARAN KOMPETENSI PEDAGOGIK GURU DALAM MENGAJAR SISWA TUNARUNGU. Widya Dharma: Jurnal Kependidikan, 26(2), 161-182.

Ilechukwu, G. C., Ilechukwu, C. G. A., Ezeanolue, B. C., Okoroafor, I. J., Ojinnaka, N. C., Ubesie, A. C., Emechebe, G. O., \& Eze, J. (2016). Ear-related problems among children attending the paediatric and otorhinolaryngology out-patients clinics of the University of Nigeria Teaching Hospital, Enugu. African Health Sciences, 16(2), 363-366.

Löfkvist, U., Bäckström, K., Dahlby-Skoog, M., Gunnarsson, S., Persson, M., \& Lohmander, A. (2020). Babbling and consonant production in children with hearing impairment who use hearing aids or cochlear implants-a pilot study. Logopedics Phoniatrics Vocology, 45(4), 172-180.

Mujahida, M. (2018). Problematika Pelayanan terhadap Anak Tuna Rungu di Sekolah Luar Biasa Jenetallasa Kecamatan Pallangga Kabupaten Gowa. Universitas Islam Negeri Alauddin Makassar.

Organization, W. H. (2018). Addressing the rising prevalence of hearing loss.

Parhoon, K., Movallali, G., \& Hassan-Zadeh, S. (2014). Attitude of Regular and Itinerant Teachers Towards the Inclusion of Hearing Impairment Children. Iranian Rehabilitation Journal, 12(4), 22-28.

Prakash, S. S. (2012). Inclusion of children with hearing impairment in schools: A survey on teachers' attitudes. Disability, CBR \& Inclusive Development, 23(3), 90-111.

Prawistri, A. R. H., \& Restu, A. (2013). Upaya meningkatkan rasa percaya diri anak Kelompok B melalui kegiatan bermain aktif di TK Pembina Kecamatan Bantul. Program Studi Pendidikan Guru Pendidikan Anak Usia Dini. Jurusan Pendidikan Pra Sekolah Dan Sekolah Dasar. Fakultas Ilmu Pendidikan Universitas Negeri Yogyakarta. Yogyakarta.

Rahayu, S. M. (2013). Memenuhi Hak Anak Berkebutuhan Khusus Anak Usia Dini Melalui Pendidikan Inklusif. Jurnal Pendidikan Anak, 2(2).

Rahmah, F. N. (2018). Problematika anak tunarungu dan cara mengatasinya. Quality, 6(1), 1-15.

Rekkedal, A. M. (2017). Factors associated with school participation among students with hearing loss. 
Scandinavian Journal of Disability Research, 19(3), 175-193.

Restendy, S. (2019). Model Belajar Dan Komunikasi Anak Disabilitas Tunarungu Wicara Di Taman Pendidikan Al Quran Luar Biasa (Tpqlb) Spirit Dakwah Indonesia Tulungagung. Jurnal Komunika Islamika: Jurnal Ilmu Komunikasi Dan Kajian Islam, 6(1), 58-74.

Rifayanti, R., Saputri, A., Arake, A. K., \& Astuti, W. (2018). Peran Role Model Dalam Membentuk Perilaku Pro-Lingkungan. Psikostudia: Jurnal Psikologi, 7(2), 12-23.

Robi'in, B., \& Tyas, Z. A. (2018). Desain Aplikasi Mobile Panduan Sholat Dan Doa Untuk Anak Gangguan Pendengaran. ILKOM Jurnal Ilmiah, 10(3), 290-297. Salamah, U. (2015). Kesiapan Guru Kelas Dalam Menangani Anak Berkebutuhan Khusus di SD N Pojok Kabupaten Sleman. Basic Education, 4(13).

Satria, D., Amsyaruddin, A., \& Marlina, M. (2018).

Meningkatkan Keterampilan Membuat Kotak Tisu Melalui Pendekatan PAKEM Bagi Anak Tunarungu. Jurnal Pendidikan Kebutuhan Khusus, 2(1), 22-25.

Shepherd, C. M., \& Alpert, M. (2015). Using Technology to Provide Differentiated Instruction for Deaf Learners. Journal of Instructional Pedagogies, 16.

Siron, Y. (2018). Implementing Inclusive Education: What are Elementary Teacher Obstacles? Case Study in East Jakarta , Indonesia. 153(Icddims 2017), 177-180.

Siron, Y., Ningrum, H. S., Gustiani, L., \& Muaz, F. (2020). Father's Involvement in Parenting Children With Cerebral Palsy. Journal Early Childhood Education, 2(2), 183-196.

Stevens, G., Flaxman, S., Brunskill, E., Mascarenhas, M., Mathers, C. D., \& Finucane, M. (2013). Global and regional hearing impairment prevalence: an analysis of 42 studies in 29 countries. The European Journal of Public Health, 23(1), 146-152.

Sugiarti, S. (2016). Upaya meningkatkan kosa kata anak tunarungu melalui media variasi gambar pada siswa kelas V/B di SLB Negeri Surakarta. Prosiding Ilmu Pendidikan, $1(2)$.

Tarnoto, N. (2016). Permasalahan-permasalahan yang dihadapi sekolah penyelenggara pendidikan inklusi pada tingkat SD. Humanitas: Jurnal Psikologi Indonesia, 13(1), 5061. 
Zakia, D. L., Sunardi, S., \& Yamtinah, S. (2016). Pemilihan dan Penggunaan Media dalam Pembelajaran IPA Siswa Tunarungu Kelas XI Di Kabupaten Sukoharjo. Sainsmat: Jurnal Ilmiah Ilmu Pengetahuan Alam, 5(1).

Zirzow, N. K. (2015). Signing avatars: Using virtual reality to support students with hearing loss. Rural Special Education Quarterly, 34(3), 33-36. 